\title{
Metastatic meningioma to the eleventh dorsal vertebral body: total en bloc spondylectomy. Case report and review of the literature
}

\author{
P.D. Delgado-López; V. Martín-Velasco; J.M. Castilla-Díez; O. Fernández-Arconada; *E.Mª Corrales-García; A. \\ Galacho-Harnero; A. Rodríguez-Salazar y **B. Pérez-Mies
}

Servicios de Neurocirugía y de **Anatomía Patológica. Hospital General Yagüe. Burgos. *Servicio de Oncología Radioterápica. Hospital Divino Valles. Burgos.

\section{Summary}

Introduction. One in every thousand intracranial meningiomas metastatize extracranially. Lung and intraabdominal organs are most frequently affected. Only 7\% involve vertebrae and just a dozen cases have been reported in the literature. To our knowledge, this is the first description of a total en bloc spondylectomy through a posterior approach for the treatment of an intraosseous metastatic meningioma to the eleventh dorsal vertebra.

Case report. In March 1996, a 37 year-old male underwent surgical resection for a left occipital intraventricular benign meningioma (WHO I). He was reoperated in February 2002 due to local recurrence. By the end on 2003 he developed progressively invalidating dorsolumbar pain. MRI studies revealed a T11 intraosseous mass. In March 2004, a percutaneous biopsy and vertebroplasty were performed. The pathological specimen was identified as adenocarcinoma and he initiated chemotherapy. Advice from a second pathologist was seeked, who suggested the diagnosis of intraosseous meningioma. Workup studies failed to reveal any primary tumor. In May 2004 the patient was admitted to our department and a new transpedicular biopsy confirmed the diagnosis. In June 2004 he underwent T11 total en bloc spondylectomy (Tomita's procedure), fusion with bone and calcium substitute-filled stackable carbon-fiber cages, and $\mathrm{T} 9$ to $\mathrm{L} 1$ transpedicular screw fixation. No postoperative complications ocurred and he is, so far, free from primary and secondary disease. Definite pathology: benign meningioma (WHO I).

Discussion. Distant metastases from intracranial meningiomas are rare entities, arising from benign lesions in, at least, $60 \%$ of cases. Enam et al proposed a specific pathological score to differentiate benign, atypic and malignant meningiomas. Such score correlates with the chance of metastatizing: more than $\mathbf{4 0 \%}$ in malignant meningiomas compared to $3.8 \%$ of brain

Recibido: 31-03-05. Aceptado: 19-05-05 tumors overall. The ability to metastatize seems to be linked to vascular or lifatic invasiveness. Metastases ocurr more frequently in angioblastic, papillary and meningothelial variants. Hematogenous (especially venous; Batson's perivertebral plexus), linfatic and cerebrospinal fluid are the main routes involved in the spreading of the tumor. Craniotomy itself may also play a role, for the majority of patients have been previously operated on repeatedly. The interval between the onset of the intracranial disease and the appearance of the metastasis varies from months to many years. The value of transpedicular biopsy is widely recognized (efficacy over $80 \%$ ) and the suitability of the specimen for pathological examination improves when wide inner caliber trephines are used. In the case presented we applied the oncologic concept of vertebral en bloc resection. We believe this case represents a paradigmatic indication of this technique because it respects the concepts of radical resection and spinal stability, and offers an opportunity for the curation of the disease.

KEY WORDS: Total spondylectomy. Meningioma. Metastasis, radical resection, en bloc resection.

Metástasis de meningioma en la undécima vértebra dorsal: vertebrectomía total en bloque. Caso clínico y revisión de la literatura

Resumen

Introducción. Las metástasis distantes de meningioma intracraneal ocurren en uno de cada mil meningiomas. La mayor parte afectan a pulmón u órganos intraabdominales. Sólo un 7\% aparecen en vértebras. Se han publicado en torno a una docena de casos. Presentamos la primera descripción hasta la fecha de una vertebrectomía completa por vía posterior para tratar una metástasis intraósea de meningioma benigno en el cuerpo de $\mathbf{T} 11$.

Caso clínico. Varón de 37 años de edad, intervenido en otro centro en Marzo de 1996 de meningioma benigno 
intraventricular occipital izquierdo de tipo transicional (OMS tipo I). Precisó reintervención por recidiva local en Febrero de 2002. A finales de 2003 comenzó con dolor dorsolumbar intenso y el estudio de RM espinal evidenció una masa intrósea en T11. En Marzo de 2004 se realizó biopsia transpedicular y vertebroplastia acrílica. El resultado histológico fue de adenocarcinoma y el paciente comenzó a recibir quimioterapia. Una segunda opinión sobre las muestras histológicas sugirió el diagnóstico de meningioma. El estudio de extensión tumoral no evidenció otra neoplasia primaria. En Mayo de 2004 ingresó en nuestro servicio donde se repite la biopsia transpedicular que confirma el diagnóstico de meningioma. En Junio de 2004 se realizó vertebrectomía T11 completa por vía posterior, según técnica de Tomita, artrodesis intersomática con cajas apilables de fibra de carbono rellenas de injerto óseo y sustituto cálcico, y fijación transpedicular T9 a L1. La evolución postoperatoria fue satisfactoria $y$, actualmente, se encuentra libre de enfermedad primaria y secundaria. Anatomía patológica definitiva: meningioma benigno (OMS I).

Discusión. Las metástasis distantes de meningiomas intracraneales son entidades raras que en más del $60 \%$ de los casos provienen de meningiomas benignos. Enam y cols diseñaron una gradación según parámetros histológicos para diferenciar los meningiomas benignos de los atípicos y malignos. Dicha gradación correlaciona con la probabilidad de producir metástasis distantes: más del $\mathbf{4 0} \%$ en los meningiomas malignos frente a una media del $3.8 \%$ de todos los tumores cerebrales. La posibilidad de metastatizar parece relacionarse con la capacidad de invasividad vascular o linfática. Las metástasis son más frecuentes en las variantes angioblástica, papilar y meningotelial. Se describen tres vías de diseminación: hematógena (sobre todo venosa; plexo perivertebral de Batson) linfática y por LCR. La craneotomía podría ser otra vía de diseminación pues la mayoría de los pacientes han sido previamente multioperados del tumor craneal. El tiempo transcurrido entre el diagnóstico del meningioma intracraneal y la aparición de la metástasis vertebral puede variar entre meses y años. La rentabilidad diagnóstica de la biopsia transpedicular es mayor del $\mathbf{8 0 \%}$ y mejora cuanto mayor es el diámetro interno de la trefina utilizada. En el caso descrito, aplicamos el concepto oncológico de resección en bloque de la vértebra afectada. Creemos que se trata de una indicación paradigmática de esta técnica pues respeta los conceptos de resección radical y estabilidad de la columna, y otorga una oportunidad de curación de la enfermedad.

PALABRAS CLAVE: Vertebrectomía total. Meningioma.
Metástasis. Resección radical. Resección en bloque.

Introduction

Meningiomas are common neoplasms derived from the arachnoid tissue. The incidence of meningioma in the general population has been estimated as 2-3 new cases per 100,000 every year, slightly more frequent in females (ratio 1.8:1) $)^{8,11,21,26}$. Overall, meningiomas comprise $15-20 \%$ of all primary intracranial tumors and $10-20 \%$ of all spinal tumors ${ }^{11}$. The vast majority are considered benign lesions. They present a moderate tendency to local recurrence which seems to depend on the histological type and the extent of resection. Very rarely $(0.1 \%)$ they are able to produce distant extracranial metastases. They may arise from either benign or atypical/malignant lesions after a variable period of time, lasting from a few months to several years. Lung and intraabdominal organs are most frequently affected. Long bones and vertebrae are rare sites for distant metastases $^{8,9,41}$.

Hardly a dozen vertebral intraosseous metastases originated from intracranial meningiomas are reported in the literature $8,9,20,25,41$. We describe a metastatic meningioma to the eleventh dorsal vertebral body in a patient previously operated on for a benign intraventricular meningioma. Concepts and surgical techniques of oncologic staging and resection were applied ${ }^{5}$, such as, total en bloc spondylectomy through a posterior approach (Tomita's procedure $)^{42,43}$. The literature concerning vertebral metastatic meningiomas is reviewed.

\section{Case report}

A 37 year-old male with unremarkable previous history underwent, elsewhere, surgical resection for a left occipital intraventricular meningioma in March 1996. The pathological findings were consistent with a benign tumor (transitional type; few Psammoma bodies and no mitotic activity) considered WHO class I. In February 2002 the patient presented with focal seizures and a local recurrence. He was reoperated on and the pathological study confirmed the initial diagnosis although two mitoses per ten high-power fields were then described.

By the end of 2003 the patient developed progressively invalidating dorso-lumbar pain. Spinal MRI showed a slightly circumscribed mass within the T11 vertebral body with prevertebral, but no epidural, extension. In March 2004 a percutaneous transpedicular biopsy, as well as an acrylic vertebroplasty were performed during the same procedure. Pathological findings were described as suggestive of adenocarcinoma at that time. Workup studies (whole body CT scan, bone scintigraphy, tumoral serum markers, gastroscopy and colonoscopy) revealed no primary source 
of tumor and the patient initiated empiric chemotherapy. Advice from a second pathologist was seeked regarding the biopsy material, and a diagnosis of intraosseous benign menigioma was suggested.

In May 2004 the patient was referred to our department and a new percutaneous transpedicular needle biopsy was performed. Again, the specimen was consistent with benign meningioma. In June 2004 the patient underwent T11 total en bloc spondylectomy through a single posterior approach, interbody fusion with stackable bone-filled carbon-fiber cages, and transpedicular screw fixation from T9 to L1, following Tomita's technique ${ }^{42,43}$. The patient required repositioning of two pedicular screws. He recovered uneventfully thereafter and he is, so far, free from both primary and secondary disease. Final pathological study of the resected vertebra revealed a benign intraosseous meningioma without mitoses nor other signs of malignant behaviour (WHO class I).

\section{Intervention}

The operation above mentioned needs a wide posterior midline exposure, including the proximal $4-5 \mathrm{~cm}$ of the ribs, bilaterally. The section of the pedicles is done with a special threaded saw (T-saw ${ }^{\mathrm{TM}}$, DePuy Spine, Johnson\&Johnson, Raynham, MA., U.S.A.) introduced through the foramen, around the pedicle, inside a thin maleable guide. It is neccessary to resect the proximal $3-4 \mathrm{~cm}$ of the ribs, including their heads, in order to remove the posterior arch in one piece. Segmental radicular vessels must be identified and divided on both sides. The remaining vertebral body needs to be dissected away from the surrounding structures: parietal pleural, prevertebral soft tissue, aorta and dura. Prevertebral dissection is done bluntly by using the fingertips of both hands until the guide for the $\mathrm{T}-\mathrm{saw}^{\mathrm{TM}}$ can be introduced around the vertebral body. Dura mater is gently dissected away from the posterior longitudinal ligament and venous epidural bleeding is controlled. At this point, unilateral pedicle screw fixation is mandatory. The vertebral body is cut at the level of the superior and inferior disks, taking special care not to damage the dural sac when approaching the posterior wall (a wide spatula behind the sac is strongly recommended). Once the disks are sectioned, it is helpful to perform gentle distraction. This allows easier removal of the vertebra through the opposite side of the fixation. Careful hemostasis is generally required at this stage. The intersomatic cages (Stackable Cages ${ }^{\mathrm{TM}}$, DePuy Spine, Johnson\&Johnson, Raynham, MA., U.S.A.) are filled with bone or other substitute (pieces of the resected ribs can be used if tumoral invasion has been previously ruled out) and introduced by the side until a proper anterior location is achieved. Then, posterior fixation is completed (Monarch Spine System ${ }^{\mathrm{TM}}$, DePuy Spine,
Johnson\&Johnson, Raynham, MA., U.S.A.). Additional material (we used calcium carbonate chips and fibrin glue) can be placed bilaterally to enforce fusion. Standard closure is performed and a wound aspirative drain may be left. The patient is allowed to ambulate (wearing a corset) after 2-3 days if no postoperative complications occur. We routinely use intraoperative irrigation with antibiotic-Ringer dilution and also postoperative low molecular weight heparin and wide-spectrum antibiotics.

Figure 1 shows preoperative MRI studies; Figure 2 details several stages of the en bloc vertebral resection; Figure 3 shows macroscopic as well as microscopic pathological views of the specimen; and Figure 4 shows postoperative X-rays: fusion and instrumentation devices.

\section{Discussion}

Distant metastases from intracranial meningiomas are rare entities with an estimated incidence of one in every thousand meningiomas ${ }^{12,17,31,32,35,36}$. In their own experience, Enam et $\mathrm{aI}^{8}$ have reported an incidence ten times higher (1\%) over 396 surgically resected meningiomas. They also reported a $43 \%$ chance of metastatic spread when only malignant meningiomas were considered.

\section{Metastatic meningiomas}

Over a hundred cases of extracranial metastases arising from intracranial meningiomas are reported in the recent literature $8,17,41$. About $60 \%$ of such distant metastases are localized in lungs; around 30\% affect intraabdominal organs (mainly liver), and just $10 \%$ spread to the bones ${ }^{17,31,32}$. Only $7 \%$ occur in vertebrae ${ }^{17,45}$. A few cases of spinal metastases have been published to date ${ }^{2,16,20,22,26,28,34,46}$. Some of them were intrarrachidian metastases ${ }^{7,19}$ and others were intraosseous; in C-2 ${ }^{41}, \mathrm{~T}-1^{9}, \mathrm{~T}-10^{8}, \mathrm{~L}-2^{8}, \mathrm{~L}-5^{25}$, sacrum ${ }^{20}$ and multiple ${ }^{8}$. Three cases were pathologically unconfirmed ${ }^{19}$ (see Table 1 for a detailed description of these cases).

From an empiric and pathological point of view, it does not seem possible to dearly differentiate a vertebral metastatic meningioma from another developed de novo within the vertebra. Citogenetic studies ${ }^{6}$ may contribute to elucidate their true origin although not an evident influence in their therapeutic management should be expected. Primary extracranial meningiomas may arise in unusual locations, other than leptomeninges and choroid plexuses, such as vertebrae. Typical meningiomas originate from arachnoid cap cells near arachnoid villi, structures that do not belong to the central nervous system itself but which are present nearby the anatomical limits of the blood-brain barrier. This may explain why meningiomas, overall, tend to metastatize more frequently than primary neuroepithelial brain tumors ${ }^{8,12}$. 


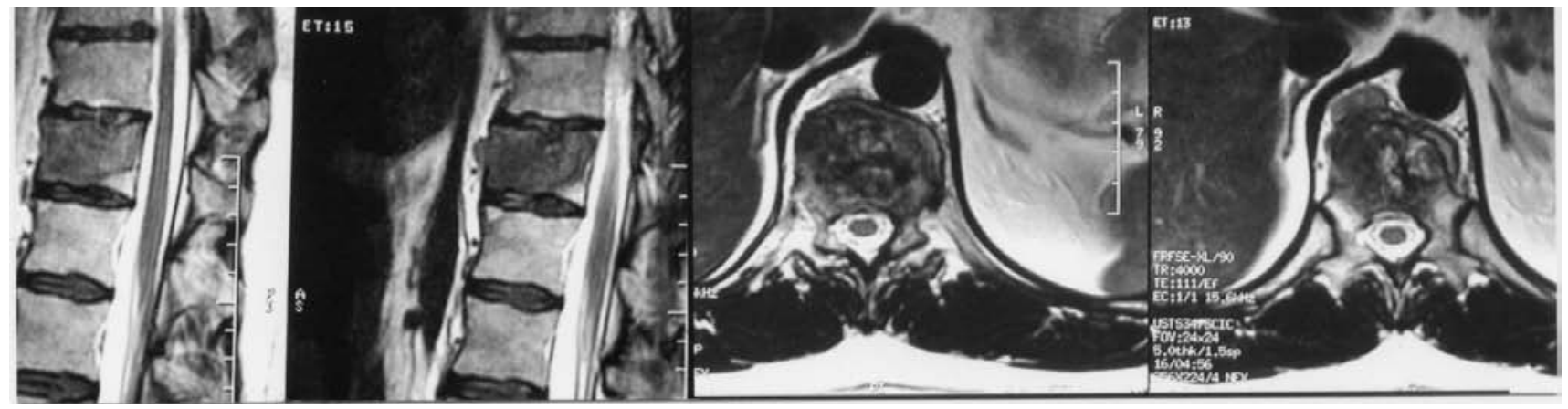

Figure1. Preoperative spinal magnetic resonance images: intraosseous T11 mass with prevertebral paraaortic extension.

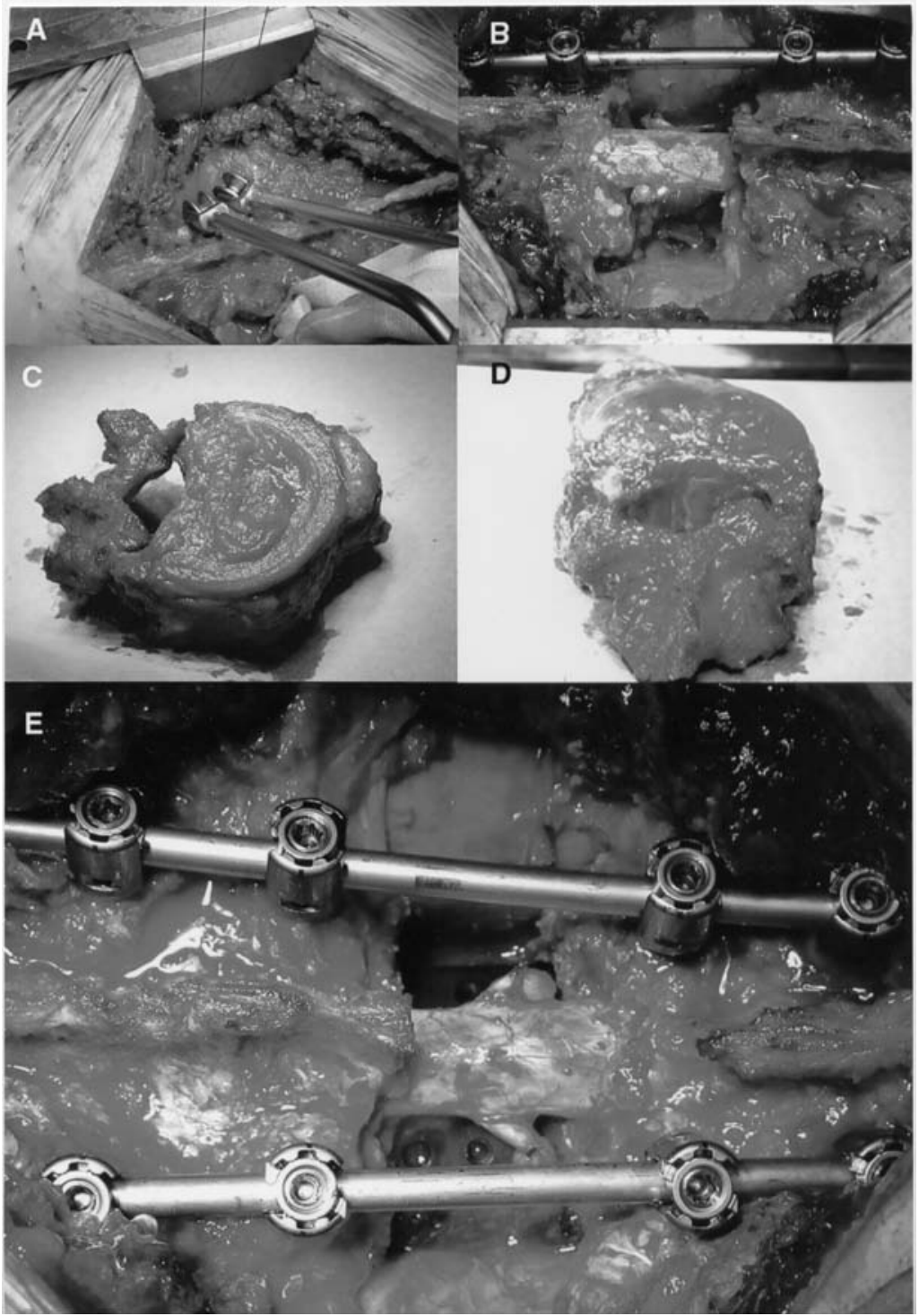

Figure 2. A: Horizontal cut of vertebral pedicles using the threaded saw (T-Saw ${ }^{T M}$, DePuy Spine, Johnson\&Johnson, Raynham, MA., U.S.A.) and pulley device for posterior arch en bloc removal.

B. En bloc T11 corpectomy after unilateral pedicular fixation. Note that both nerve roots need to be ligated and sectioned for dissecting the vertebral body away from the pleura, aorta and dura, in order to remove the vertebral body and pellicles in one piece. Segmental radicular vessels need also to be divided. $C$ : Superolateral view of the resected vertebra. Note the prevertebral extension in the anterior aspect of the vertebral body.

D: Posterior view of the resected vertebra. E: Stackable carbon-fiber cages are used for interbody fusion (Stackable Cages ${ }^{T M}$, DePuy Spine, Johnson\&Johnson, Raynham, MA., U.S.A.). Afterwards, pedicular screw fixation is completed (Monarch Spine System ${ }^{T M}$, DePuy Spine, Johnson\&Johnson, Raynham, MA., U.S.A.). See explanation in the text.

Although $90 \%$ of intracranial meningiomas are histologically benign ${ }^{7,21,24}$, more than $60 \%$ of the distant metastases reported are paradoxically originated from them ${ }^{8,31,35,40}$. Nevertheless, distant metastases are known to be relatively more frequent arising from atypical or malignant subty$\operatorname{pes}^{7,8,21}$.

Atypical and malignant meningiomas (only $1.7-4.2 \%$ of all $)^{21,24}$, differ from benign lesions according to several 


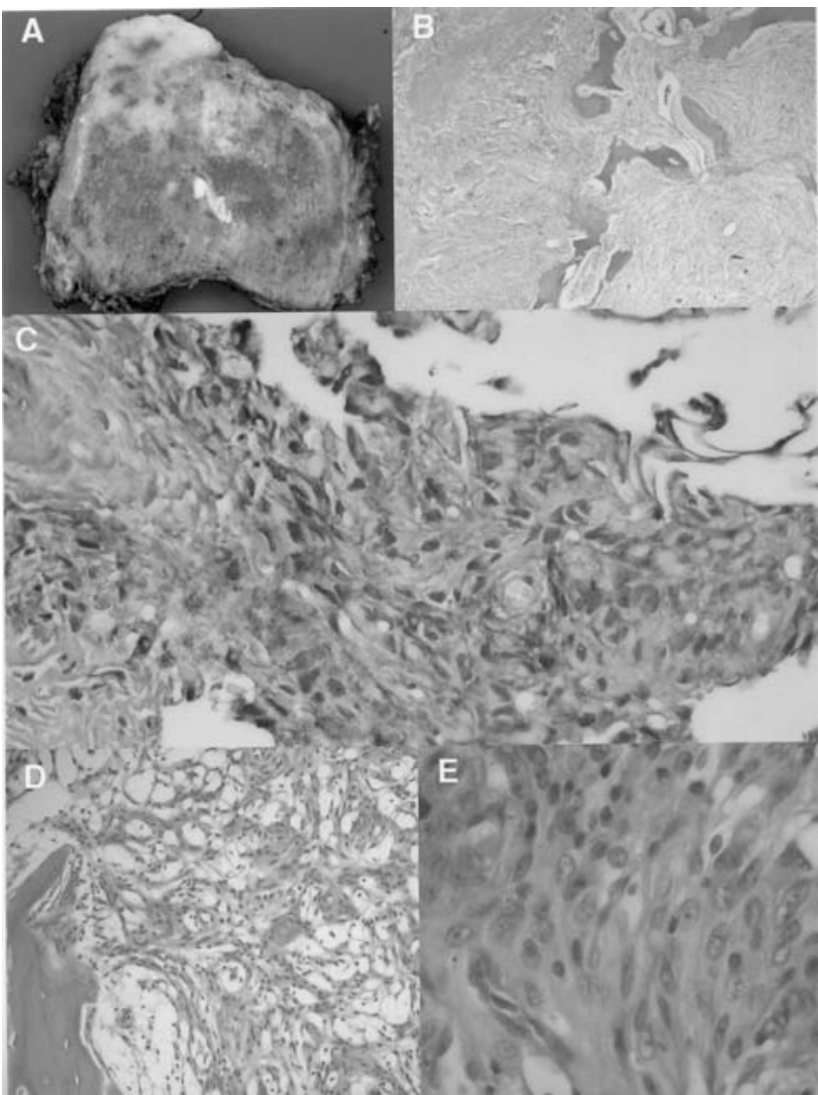

Figure 3. A: Macroscopic view of the affected vertebral body: intraosseous yellowish spotted lesion infiltrating the vertebral body, with anterior extravertebral extension.

B: Microscopic view corresponding to hematoxylin-eosin stain of the specimen in the area of transition between intraosseous tumoral proliferation, cortical vertebral bone and prevertebral tumoral extension.

C: Microscopic view of marked EMA (Epithelial Membrane Antigen) positivity of tumoral cells.

D: Meningothelial cells with clear foamy histiocytes. Osteoid matrix and ostocytes are visible in the left lower comer of the image.

E: Detail of meningothelial cells: no figures of mitosis or nuclear atypia can be observed.

histological features, such as, increased mitotic activity (more than four mitotic figures in atypical and more than twenty mitoses in malignant, per ten high-power fields), increased cell density, presence of nuclear pleomorphism, loss of architectural cell disposition, existence of tumoral necrosis and brain invasion, papillary transformation and carcinoma, melanoma or sarcomatous appearance $\mathrm{e}^{7,8,9,18,21,39}$.

Enam et $\mathrm{al}^{8}$ classified meningiomas in benign, atypical and malignant according to the above mentioned features. They proposed a simple 0-3 specific score involving just six items: hypercelularity, loss of architecture, nuclear

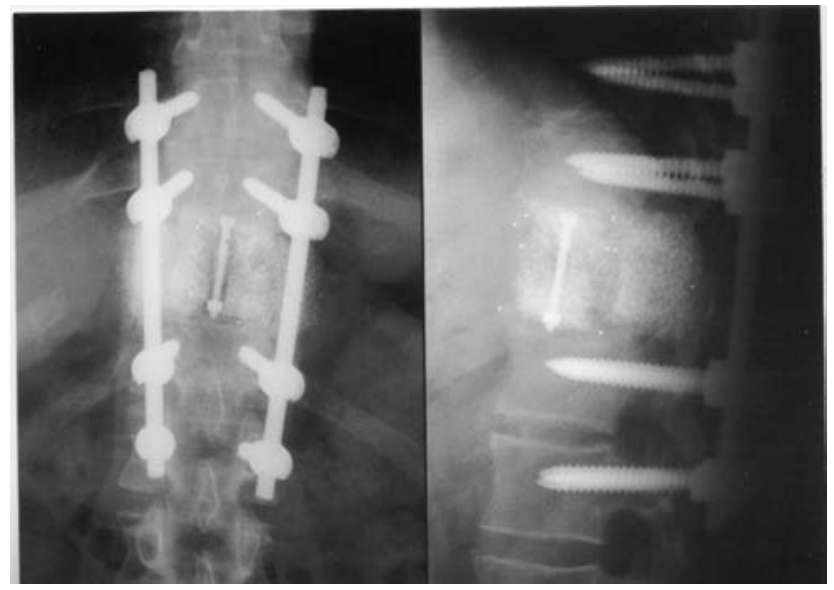

Figure 4. Postoperative X-ray examination: correct alignment of the interbody fusion material and multi-level pedicular screw fixation is shown.

pleomorphism, high mitotic index, tumor necrosis and brain invasion. Thus, meningiomas scoring 0-4 points were considered benign, those scoring 5-11 were atypical and those over 11 points were malignant (for a detailed explanation, see Mahmood et $\mathrm{al}^{24}$ ). The higher the score, the higher the risk of distant metastasis: more than $40 \%$ in malignant versus an average of $3.8 \%$ for all intracranial tumors. According to World Health Organization Classification of tumors of the nervous system (published in 2000) ${ }^{21}$, types II (atypical, clear cell and chordoid variants) and III (rabdoid, papillary and anaplastic variants), and the presence of brain invasion in either benign or malignant meningiomas, seem to favour metastatic spread. Hemangiopericytomas are no longer considered a subtype of meningiomas and they are actually classified separately. They also metastatize rather frequently $(23 \%)^{8}$.

The fact that distant metastases may originate from benign meningiomas suggest that this capacity may be linked to the ability of the tumor to produce vascular and linfatic invasion (secretion of substances such as colagenase), rather than to the pattern of growth or the mitotic index ${ }^{4,13}$. In fact, the chances of metastatic disease are higher in angioblastic, papillary and meningothelial variants $^{21,31,32}$. The ability to metastatize does not seem to be related to the primary intracranial location and dubiously to the type of intervention or the extent of resection ${ }^{17,23}$.

Meningiomas seem to metastatize via three main routes: hematogenous, linfatic and through the cerebrospinal fluid $^{8,18,22,23,41.47}$. It is generally accepted that hematogenous spread is the most common pathway, especially through the veins, given its tendency towards lung and liver invasion. It has been deemed reasonable to relate vertebral metastatic involvement to the existence of Batson's perivertebral venous plexus ${ }^{3,20}$. Malignant meningiomas (more prevalent 
Table 1

Vertebral metastatic meningiomas reported in the literature. (WHO: World Health Organization)

\begin{tabular}{|c|c|c|c|c|c|}
\hline Author & Sex, age & $\begin{array}{l}\text { Intracranial } \\
\text { Meningioma }\end{array}$ & $\begin{array}{l}\text { Local } \\
\text { Recurrence }\end{array}$ & $\begin{array}{l}\text { Vertebral } \\
\text { Lesion }\end{array}$ & $\begin{array}{l}\text { Comments, } \\
\text { Follow up }\end{array}$ \\
\hline $\begin{array}{l}\text { Fuentes S et } \\
\mathrm{al}^{9}, 2002 .\end{array}$ & Female, 63. & $\begin{array}{l}\text { Benign right fronto- } \\
\text { parietal convexity } \\
\text { meningioma (WHO I). } \\
\text { Complete resection. }\end{array}$ & $\begin{array}{l}\text { At } 3 \text { years: } \\
\text { radiosurgery. } \\
\text { At } 10 \text { years: } \\
\text { reintervention: } \\
\text { atypical } \\
\text { meningioma } \\
\text { (WHO II) }\end{array}$ & $\begin{array}{l}\text { At } 11 \text { years: } \\
\text { intraosseous T1 } \\
\text { metastasis. } \\
\text { Radiation therapy } \\
\text { (20 Gy) from C7 to } \\
\text { D2. Corpectomy } \\
\text { and C7-T2 } \\
\text { arthrodesis } \\
\text { (WHO II) }\end{array}$ & $\begin{array}{l}\text { At } 5 \text { years: breast } \\
\text { ca. } \\
\text { No cranial } \\
\text { recurrence after } \\
\text { second operation. } \\
\text { Recurrent nerve } \\
\text { palsy after } \\
\text { operation. }\end{array}$ \\
\hline $\begin{array}{l}\text { Lee YY et } \\
\mathrm{a}^{20}, 2002 .\end{array}$ & Female, 48. & $\begin{array}{l}\text { Right frontal } \\
\text { convexity } \\
\text { meningioma } \\
\text { (meningothelial and } \\
\text { angioblastic, WHO I). } \\
\text { Preop embolization } \\
\text { and complete } \\
\text { resection. }\end{array}$ & $\begin{array}{l}\text { At } 3 \text { years: small } \\
\text { local recurrence. } \\
\text { At } 4 \text { years: } \\
\text { reintervention. }\end{array}$ & $\begin{array}{l}\text { At } 3 \text { years: left } \\
\text { sacral intraosseous } \\
\text { metastasis. Biopsy } \\
\text { and complete } \\
\text { resection: same } \\
\text { meningioma as in } \\
\text { brain, WHO I }\end{array}$ & $\begin{array}{l}\text { Free from disease } \\
\text { after } 16 \text { months. } \\
\text { Mild sphyncter } \\
\text { impairment after } \\
\text { S2-level } \\
\text { sacrectomy }\end{array}$ \\
\hline $\begin{array}{l}\text { Conrad MD } \\
\text { et } \mathrm{al}^{7}, 2001 \text {. }\end{array}$ & Female, 31. & $\begin{array}{l}\text { Right fronto-temporal } \\
\text { convexity transitional } \\
\text { meningioma (WHO I) } \\
\text { Complete resection. }\end{array}$ & $\begin{array}{l}\text { At } 3 \text { years: } \\
\text { reintervention } \\
\text { atypical (WHO II) } \\
\text { At } 5 \text { years: } \\
\text { radiation therapy } \\
\text { (60 Gy). } \\
\text { At } 7 \text { years: } \\
\text { reintervention; } \\
\text { atypical (WHO II). } \\
\text { Bromocriptine. }\end{array}$ & $\begin{array}{l}\text { At } 8 \text { years: Spinal } \\
\text { L5-S1 metastasis. } \\
\text { Laminectomy and } \\
\text { resection (WHO II, } \\
\text { atypical). } \\
\text { Recurrence after } 8 \\
\text { months: resection } \\
\text { (WHO III, } \\
\text { malignant) }\end{array}$ & $\begin{array}{l}\text { Malignization of } \\
\text { primary lesion. }\end{array}$ \\
\hline \multirow[t]{2}{*}{$\begin{array}{l}\text { Lee TT et } \\
\mathrm{al}^{19}, 1998 .\end{array}$} & Male, 59. & $\begin{array}{l}\text { Left hemispheric } \\
\text { malignant menigioma } \\
\text { (WHO Ill). } \\
\text { Complete resection. }\end{array}$ & $\begin{array}{l}\text { At } 6 \text { months: } \\
\text { reintervention + } \\
\text { radiation therapy } \\
(55 \mathrm{~Gy})+ \\
\text { chemotherapy. } \\
\text { At } 2 \text { years: } \\
\text { radiosurgery ( } 15 \\
\text { Gy) + radiotherapy }\end{array}$ & $\begin{array}{l}\text { At } 27 \text { months: } \\
\text { multiple cauda } \\
\text { equina metastases. } \\
\text { Radiation therapy } \\
\text { ( } 37,5 \text { Gy) from L1 to } \\
\text { S2 }\end{array}$ & $\begin{array}{l}\text { Dead at } 3 \text { years. } \\
\text { Unconfirmed } \\
\text { pathology. }\end{array}$ \\
\hline & Male, 65. & $\begin{array}{l}\text { Malignant petroclival } \\
\text { meningothelial } \\
\text { meningioma (WHO } \\
\text { Ill). } \\
\text { Complete resection }\end{array}$ & $\begin{array}{l}\text { At } 43 \text { months: } \\
\text { reintervention } \\
\text { (WHO Ill) } \\
\text { At } 45 \text { months: } \\
\text { reintervention. } \\
\text { At } 57 \text { months: } \\
\text { reintervention. }\end{array}$ & $\begin{array}{l}\text { At } 62 \text { months: spinal } \\
\text { L5-S1 mestastasis. } \\
\text { Radiation therapy } \\
(37,5 \mathrm{~Gy}) .\end{array}$ & $\begin{array}{l}\text { Eighty months } \\
\text { survival in } 1998 \\
\text { Unconfirmed } \\
\text { pathology }\end{array}$ \\
\hline
\end{tabular}




\begin{tabular}{|c|c|c|c|c|c|}
\hline & Male, 39. & $\begin{array}{l}\text { Left frontal syncytial } \\
\text { malignant } \\
\text { meningioma (WHO } \\
\text { III). } \\
\text { Complete resection. }\end{array}$ & $\begin{array}{l}\text { Five recurrences } \\
\text { operated on } \\
\text { (dates?) } \\
\text { Radiation therapy } \\
55 \text { Gy after second } \\
\text { resection and } 45 \\
\text { Gy after resection } \\
\text { at } 105 \text { month. }\end{array}$ & $\begin{array}{l}\text { At } 105 \text { months: } \\
\text { multiple spinal } \\
\text { metastases in } \\
\text { thoracolumbar area. } \\
\text { Radiation therapy } \\
\text { (36 Gy). }\end{array}$ & $\begin{array}{l}\text { Dead ad } 108 \\
\text { months } \\
\text { Unconfirmed } \\
\text { pathology. }\end{array}$ \\
\hline \multirow[t]{3}{*}{$\begin{array}{l}\text { Enam SA } \\
\text { et } \mathrm{al}^{8}, 1996 .\end{array}$} & Female, 73. & $\begin{array}{l}\text { Fronto-parietal } \\
\text { meningothelia- } \\
\text { synsytial malignant } \\
\text { meningioma (WHO } \\
\text { III). Bone invasion. } \\
\text { Complete en bloc } \\
\text { resection. }\end{array}$ & $\begin{array}{l}\text { At } 8 \text { months: } \\
\text { reintervention and } \\
\text { Radiation therapy }+ \\
\text { Radiosurgery. }\end{array}$ & $\begin{array}{l}\text { At } 11 \text { months: T10 } \\
\text { intraosseous } \\
\text { metastasis } \\
\text { (WHOIII). Large } \\
\text { liver metastasis. }\end{array}$ & $\begin{array}{l}\text { Brown-Sequard } \\
\text { syndrome. }\end{array}$ \\
\hline & Male, 50 & $\begin{array}{l}\text { Right fronto-parieto- } \\
\text { occipital malignant } \\
\text { meningioma (WHO } \\
\text { III). } \\
\text { Resection + } \\
\text { Radiation therapy }\end{array}$ & $\begin{array}{l}\text { At } 16 \text { months: } \\
\text { reintervention } \\
\text { (WHO Ill). }\end{array}$ & $\begin{array}{l}\text { At } 17 \text { months: } \\
\text { multiple cervical and } \\
\text { dorsal-lumbar } \\
\text { metastases. } \\
\text { Palliative treatment }\end{array}$ & $\begin{array}{l}\text { Dead after two } \\
\text { weeks. } \\
\text { Unconfirmed } \\
\text { pathology of } \\
\text { spinal lesions. }\end{array}$ \\
\hline & Female, 52. & $\begin{array}{l}\text { Right sphenoid wing } \\
\text { malignant } \\
\text { meningioma (WHO } \\
\text { III). } \\
\text { Resection }+ \\
\text { Radiation therapy. }\end{array}$ & $\begin{array}{l}\text { At } 14 \text { months: } \\
\text { reintervention + } \\
\text { adriamycin (WHO } \\
\text { III). } \\
\text { At } 20 \text { months: Five } \\
\text { cm recurrence. }\end{array}$ & $\begin{array}{l}\text { At } 18 \text { months: L2 } \\
\text { metastasis } \\
\text { (pathological } \\
\text { fracture) and femur } \\
\text { metastasis. L1-L2 } \\
\text { corpectomy }+ \\
\text { acrylic fusion }+ \\
\text { Radiation therapy } \\
\text { (WHO III). }\end{array}$ & $\begin{array}{l}\text { At } 20 \text { months: } \\
\text { pelvic } \\
\text { metastases. } \\
\text { Dead } \\
\text { due to disease } \\
\text { progression. }\end{array}$ \\
\hline $\begin{array}{l}\text { Tominaga T } \\
\text { et al } 41 \text {, } \\
1994 \text {. }\end{array}$ & Female, 41. & $\begin{array}{l}\text { Right parasagittal } \\
\text { transitional } \\
\text { meningioma (WHO I) } \\
\text { Subtotal resection. }\end{array}$ & $\begin{array}{l}\text { At } 13 \text { years: small } \\
\text { left parietal } \\
\text { recurrence. }\end{array}$ & $\begin{array}{l}\text { At } 13 \text { years: } \mathrm{C} 2 \\
\text { intraosseous } \\
\text { metastasis. } \\
\text { Posterior } \\
\text { decompression }+ \\
\text { biopsy (transitional } \\
\text { meningioma) + } \\
\text { Hartshill posterior } \\
\text { fixation+ transoral } \\
\text { resection after } 3 \\
\text { months. }\end{array}$ & $\begin{array}{l}\text { No morbidity. } \\
\text { Parietal } \\
\text { recurrence was } \\
\text { not treated. } \\
\text { Possible } \\
\text { dissemination } \\
\text { via superior } \\
\text { sagittal } \\
\text { sinus. }\end{array}$ \\
\hline $\begin{array}{l}\text { Palmer JD } \\
\text { et al }^{25} \text {, } \\
1994 \text {. }\end{array}$ & Male, 55. & $\begin{array}{l}\text { Posterior fossa } \\
\text { meningioma without } \\
\text { lateral sinus invasion. } \\
\text { Complete resection. }\end{array}$ & $\begin{array}{l}\text { At } 8 \text { years: occipital } \\
\text { and posterior fossa } \\
\text { recurrence. } \\
\text { Resection } \\
\text { (hemangioperycitic). } \\
\text { Postop radiation } \\
\text { therapy. } \\
\text { At } 12 \text { years: } \\
\text { occipital } \\
\text { recurrence. }\end{array}$ & $\begin{array}{l}\text { At } 12 \text { years: L5 } \\
\text { intraosseous } \\
\text { metastasis. } \\
\text { Transpedicular and } \\
\text { open biopsy of L5: } \\
\text { Same pathology. } \\
\text { Palliative radiation } \\
\text { therapy }\end{array}$ & $\begin{array}{l}\text { Dead at } 6 \\
\text { months due } \\
\text { to refractory } \\
\text { hypercalcemia }\end{array}$ \\
\hline
\end{tabular}


in male ${ }^{21}$ ) seem to spread through the cerebrospinal fluid more frequently ${ }^{18,39}$. Once inside the vertebral body, the tumor may reach other vertebral levels by growing beneath the posterior longitudinal ligament (considered a weak anatomical barrier) to the epidural space, or through the paraspinal muscles to the nearby laminae ${ }^{10}$.

It remains controversial whether craniotomy itself may play a role in the spread of the tumor, especially in those patients harbouring intraventricular lesions, as in the case above. The fact that most patients are operated on several times before a metastasis occurs, supports this idea, although some cases seem to occur in non-operated patients, as well $1^{18,37}$.

There is quite a variable latency period between the diagnosis of the intracranial tumor and the appearance of the metastasis, ranging from a few months to more than twenty years ${ }^{23,30}$. The intracranial lesion usually recurs locally several times before it metastatizes. This interval appears to be shorter for atypical and malignant tumors (about a year) compared to benign lesions (over five years). The explanation for this variety remains unclear. It should be remembered that the overall recurrence rate of totally resected meningiomas is $11-15 \%$ and, as much as, $30 \%$ for partially resected ones ${ }^{11}$. The estimated recurrence rate for benign meningiomas is $3 \%$ after 5 years and $31 \%$ after 25 years. These figures turn to $38 \%$ for atypical and $50-78 \%$ for malignant after 5 years ${ }^{8,14}$.

\section{Total en bloc vertebrectomy}

The management of metastatic disease of any kind is generally considered to be palliative. En bloc excision of a solitary vertebral metastasis originated from a resected intracranial meningioma is, in our opinion, a paradigm of radical oncologic resection. It provides a chance for a possible cure of the disease with acceptable surgical risks ${ }^{42,43}$. Radiation and chemotherapy do play a role especially in pathologically aggressive lesions and after local recurrence.

In the case presented we applied the concept of complete en bloc vertebral resection, carefully described by Tomita et al for both vertebral metastases ${ }^{43}$ and primary vertebral tumors ${ }^{42}$. Due to the anatomical location of the dural sac, the most radical manouver for total spondylectomy involves the removal of the vertebra in two pieces: posterior arch and vertebral body, separately ${ }^{5}$. Such resection must neccessarily be accompanied by circunferencial stabilization of the spinal axis. This procedure includes interbody fusion (bone or other substitute may be used to fill stackable high-ressistance carbon-fiber cages) and internal fixation (pedicular screws and bars placement). Akamaru et $\mathrm{al}^{1}$ have reported adecuate spine reconstruction and bony fusion in a postmortem study of a patient who had undergone an en bloc spondylectomy for Ewing's sarcoma. Interestingly, Tomita's technique allows both resection and stabilization in a single posterior approach, which it is believed to reduce the morbidity of a combined approach. For a detailed description of the technique, indications and surgical risks we refer the reader to the original papers ${ }^{42,43}$.

The value of percutaneous biopsy for vertebral tumors is widely recognized. The transpedicular approach is known to be safe and effective in about $80 \%$ of $\operatorname{cases}^{15,27,38}$. In the case presented, a wrong pathological identification of the specimen led to an initial confusion, which delayed the real diagnosis, and supported the use of unneccessary chemotherapy. A wider inner caliber of the biopsy trephine seems to correlate with the quality of the specimen obtained and its suitability for pathological examination ${ }^{44}$.

The prognosis of these patients depends on the histological grade, which in turn conditionates both primary and secondary disease's response to the treatment applied ${ }^{9}$. Table 1 summarizes several items of the cases published to date. Only five cases were originally benign tumors (one malignized after recurrence). Surgical resection was used only in benign lesions and in just one malignant tumor, with variable results. Palliative radiation therapy was the preferred modality of treatment. The extraosseous lesions reported by Lee et aI ${ }^{19}$ could not be pathologically confirmed. The authors describe several surgical procedures including partial bilateral sacrectomy, T1, L2 and C2 corpectomies and internal fixation, through some well-known approaches. The surgical option we chose is original in the context of surgical indication and, we believe, appropriate in terms of efficacy and safety. Further follow-up should confirm this statement.

To our best knowledge this is the first description of a total en bloc thoracic spondylectomy through a single posterior approach for a benign metastatic meningioma. Intraosseous vertebral metastatic meningiomas are rare entities suitable for radical resection, that provide a chance for curation with acceptable surgical risks.

\section{Acknowlegments}

Maite Inclán, Rosana Girón, Carlos Escudero and Angel Velasco for their useful remarks and their help in prepairing the manuscript.

\section{References}

1. Akamaru, T., Kawahara, N., Tsuchiya, H., Kobayashi, T., Murakami, H., Tomita, K.: Healing of autologous bone in a titanium mesh cage used in anterior reconstruction after total spondylectomy. Spine 2002; 27: E329-333.

2. Akimura,T., Orita, T., Hayashida, O., Nishizaki, T., Fudaba, H.: Malignant meningiomas metastatizing through 
the cerebrospinal pathway. Acta Neurol Scand 1992; 85: 368371.

3. Batson, O.V.: The function of the vertebral veins and their role in the spread of metastases. Ann Surg 1940; 112: 138-149.

4. Black, P.M.: Meningiomas. En: Black PM, Loeffler JS (eds). Cancer of the Nervous System. Oxford; Blackwell Science, 1977; pp. 349-362.

5. Boriani, S., Weinstein, J.N., Biagini, R.: Primary bone tumors of the spine.Terminology and surgical staging. Spine 1997; 22: 1036-1044.

6. Cerdá-Nicolás, M., López-Gines, C., Pérez-Bacete, M., Roldán, P., Talamantes, F., Barberá, J.: Histologically benign metastatic meningioma: morphological and citogenetic study. Case report. J Neurosurg 2003; 98: 194-198.

7. Conrad, M.D., Schonauer, C., Pelissou-Guyotat, I., Morel, C., Madarassy, G., Deruty, R.: Recurrent lumbosacral metastases from intracranial meningioma. Report of a case and review of the literature. Acta Neurochir (Wien) 2001; 143: 935-937.

8. Enam, S.A., Abdulrauf, S., Mehta, B., Malik, G.M., Mahmood, A.: Metastasis in meningioma. Acta Neurochir (Wien) 1996; 138: 1172-1178.

9. Fuentes, S., Metellus, P., Bouvier, C., Dufour, H., Do, L., Grisoli, F.: Metastatic meningioma to the first thoracic vertebral body. A case report and review of the literature. Neurochirurgie 2002; 48: 53-56.

10. Fujita, T., Ueda, Y., Kawahara, N., Baba, H., Tomita, K.: Local spread of metastatic vertebral tumors. A histologic study. Spine 1997; 22: 1905-1912.

11. Greenberg, M.S.: Meningiomas. En: Greenberg MS (ed). Handbook of Neurosurgery, Volume One. Lakeland, Florida; Greenberg Graphics, Inc., 1997; pp. 258-261.

12. Guthrie, B.L., Ebersold, M.J., Sheithauer, B.W.: Neoplasms of the intracranial meninges. En: Youmans JR (ed). Neurological Survey. A comprehensive reference guide to the diagnosis and management of neurosurgical problems. Philadelphia; Saunders, 1990; pp. 3250-3315.

13. Halaka, A.N., Bunning, R.A., Bird, C.C., Gibson, M., Reynolds, J.J.: Production of collagenase and inhibitor (TIMP) by intracranial tumors and dura in vitro. J Neurosurg 1983; 59: 461-466.

14. Jaaskelainen, J., Haltia, M., Servo, A.: Atypical and anaplastic meningiomas: radiology, surgery, radiotherapy and outcome. Surg Neurol 1986; 25: 233-42

15. Jelinek, J.S., Kransdorf, M.J., Gray, R., Aboulafia, A.J., Malawer, M.M.: Percutaneous transpedicular biopsy of vertebral body lesions. Spine $1996 ; 21:$ 2035-2040.

16. Kamiya, K., Inagawa, T., Nagasako, R.: Malignant intraventricular menigioma with spinal metastasis through the cerebrospinal fluid. Surg Neurol 1989; 32: 213-18.

17. Karasik, J.L., Mullens, S.: A survey of metastatic meningiomas. J Neurosurg 1974; 40: 206- 212.
18. Kepes, K.K.: Meningiomas: biology, pathology and differential diagnosis. New York; Masson Publishing USA, Inc., 1982; pp. 190-200.

19. Lee, T.T., Landy, H.J.: Spinal metastases of malignant intracranial menigioma. Surg Neurol 1998; 50: 437-441.

20. Lee, Y.Y., Wen-Wei Hsu, R., Huang, T.J., Hshue, S., Wang, J.Y.: Metastatic meningioma in the sacrum: a case report. Spine 2002; 27: E100-103.

21. Louis, D.N., Scheitauer, B.W., Budka, H., Von Deimling, A., Kepes, J.J.: Meningiomas. En: Kleihues P, Cavenee WK (eds). World Health Organization Classification of Tumours. Pathology and Genetics of Tumours of the Nervous System. Lyon; IARC Press, 2000; pp. 176-184.

22. Ludwin, S.K., Conley, F.K.: Malignant meningioma metastatizing through the cerebral pathways. J Neurol Neurosurg Psychiatry 1975; 38: 136-142.

23. Miller, D.C., Ojemann, R.G., Proppe, K.H., et al. Benign metastatic meningioma: case report. J Neurosurg 1985; 62: 763-766.

24. Mahmood, A., Caccamo, D.V., Tomecek, F.J., Malik, G.M.: Atypical and malignant meningiomas: a clinicopathological review. Neurosurgery 1993; 33: 955-963.

25. Palmer, J.D., Cook, P.L., Ellison, D.W.: Extracranial osseous metastases from intracranial meningioma. $\mathrm{Br} \mathrm{J}$ Neurosurg 1994; 8: 215-218.

26. Peh, W.C., Fan, Y.W.: Case report: intraventricular meningioma with cerebellopontine angle and drop metastases. Br J Radiol 1995; 68: 428-430 (abstract).

27. Pierot, L., Boulin, A.: Percutaneous biopsy of the thoracic and lumbar spine: transpedicular approach under fluoroscopic guidance. AJNR Am J Neuroradiol 1999; 20: 23-25.

28. Riley, C.G.: Metastatizing meningeal tumor case report. N Z Med J 1974; 73: 210-14 (abstract).

29. Rohringer, M., Sutherland, G.R., Louw, D.F., Sima, A.A.F.: Incidence and clinicopathological features of meningioma. J Neurosurg 1989; 71: 665-672.

30. Russell, T., Moss, T.: Metastatizing meningioma. Neurosurgery $1985 ; 19: 1028-1030$.

31. Salcman, M.: Malignant meningiomas. En: Al-Mefti O (ed). Meningioma. New York; Raven Press, 1991; pp. 75-85.

32. Shuangshoti, S., Hongsaprabhas, C., Netsky, M.G.: Metastatizing meningiomas. Cancer 1970; 26: 832-841.

33. Simpson, D.: Recurrence of intracranial meningiomas after surgical treatment. J Neural Neurosurg Psychiatry 1957; 20: 22-39.

34. Solero, C.L., Fomari, M., Biombini, S., et al.: Spinal meningiomas: review of 174 operated cases. Neurosurgery 1989; 125: 153-160.

35. Son, P.M., Sacher, M., Strenger, S.W., et al.: "Benign" metastatizing meningiomas. AJNR Am J Neuroradiol 1987; 8: 127-130.

36. Strang, R.R., Ton, D., Nordenstam, H.: Meningioma 
with intracerebral, cerebellar and visceral metastases. J Neurosurg 1964; 21: 1098-1102.

37. Strenger, S.W., Huang, Y.P., Sachdez, V.P.: Malignant menignioma within the third ventricle: a case report. Neurosurgery $1987 ; 20: 465-468$.

38. Stringham, D.R., Hadjipavlou, A., Dzioba, R.B., Lander, P.: Percutaneous transpedicular biopsy of the spine. Spine 1994; 19: 1985-1991.

39. Thomas, H.G., Clarisse, L.D., Berry, K.: Malignant meningioma: clinical and pathological features. J Neurosurg 1981; 55: 929-934.

40. Tognetti, C., Dorati, R., Bollini, C.: Metastatic spread of benign intracranial meningiomas. J Neurosurg Sci 1987; 31: $23-27$.

41. Tominaga, T., Koshu, K., Narita, N., Yoshimoto, T.: Metastatic meningioma to the second cervical vertebral body: a case report. Neurosurgery 1994; 34: 538-540.

42. Tomita, K., Kawahara, N., Baba, H., Tsuchiya, H., Fujita, T., Toribatake, Y.: Total en bloc spondylectomy. A new surgical technique for primary malignant vertebral tumors. Spine 1997; 22: 324-333.

43. Tomita, K., Kawahara, N., Kobayashi, T., Yoshida, A., Murakami, H., Akamaru, T.: Surgical strategy for spinal metastases. Spine 2001; 26: 298-306.

44. Ward, J.C., Jeanneret, B., Oehlschlegel, C., Magerl, F.:
The value of percutaneous transpedicular vertebral bone biopsies for histologic examination. Results of an experimental histopathologic study comparing two biopsy needles. Spine 1996; 21: 2484-2490.

45. Wasserkrug, R., Peyser, E., Lichtig, C.: Extracranial bone metastases from intracranial meningiomas. Surg Neurol 1979; 12: 480-484.

46. Wippold II, F.J., Smimoitopoulos, J.G., Pilgram, T.K.: Lesions of the cauda equina: a clinical pathology review from the Armed Forces Institute of Pathology. Clin Neurol Neurosurg 1997; 9: 229-234.

47. Wu, J.K., Kasdon, D.L., Whitmore, E.L.: Metastatic meningioma to the cervical vertebra: a case report. Neurosurgery $1985 ; 17: 75-79$.

Delgado-López, P.D.; Martín-Velasco, V.; Castilla-Díez, J.M.; Fernández-Arconada, O.; Corrales-García, E.M.; Galacho-Harnero, A.; Rodríguez-Salazar, A.; Pérez-Mies, B.: Metastatic meningioma to the eleventh dorsal vertebral body: total en bloc spondylectomy. Case report and review of the literature. Neurocirugía 2006; 17: 240-249.

Correspondencia postal: Pedro David Delgado López. Servicio de Neurocirugía. Hospital General Yagüe. Avda Cid 96. 09005 Burgos. 